
\title{
Assessment of Speech Intelligibility in Five South-Eastern Bantu Languages: Critical
}

\author{
Marlene Carno Jacobson, Ph.D (Witwatersrand) \\ Department of Speech Pathology and Audiology, University of the Witwatersrand, Johannesburg \\ Anthony Traill, Ph.D (Witwatersrand) \\ Department of Linguistics, University of the Witwatersrand, Johannesburg
}

\begin{abstract}
This paper examines criteria underlying the development of tasks and materials for the measurement of speech intelligibility in five SouthEastern Bantu languages. The chief considerations include utterance length, word familiarity and structure, and phonetic balance. It is established that the foundation research necessary for devising materials in South-Eastern Bantu languages on the same basis as those of English, has not yet been conducted. Salient properties of the relevant African languages include multilingualism, dialectal variation, vocabulary differences between rural and urban speakers of the same language, borrowed words, the simple vowel systems, the fairly elaborate consonant systems, prosodic features, certail syllable structure characteristics, and noun morphology. A rationale for the use of two measures of intelligibility is presented, while the need to adapt many criteria characterising English materials is demonstrated.
\end{abstract}

\section{OPSOMMING}

Hierdie referaat ondersoek die kriteria wat onderliggend is aan die ontwikkeling van take en materiaal vir die meting van spraakverstaanbaarheid in vyf Suid-Oosterlike Bantoe tale. Die hoofoorwegings sluit lengte van witing, woordbekendheid en -struktuur, en fonetiese balans in. Dit is bevestig dat die basiese navorsing wat benodig is vir die saamstel van materiaal in Suid-Oostelike Bantoe-tale nog nie op dieselfde basis as Engels gedoen is nie. Opvallende kenmerke van die relevante Afrika-1ale is veeltaligheid, dialektiese variasies, verskille in woordeskat tussen landelike en stedelike gebruikers van dieselfde taal. leenwoorde, die eenvoudige vokaalsisteme, die betreklik uitgebreide konsonantsisteme, prosodiese kenmerke, sekere eienskappe van lettergreepstrukture, en naamwoordmorfologie. ' $n$ Rasionaal vir die gebruik van twee verstaanbaarheidsmetings is aangebied en die noodsaak om kenmerkende kriteria vir Engelse materiaal aan te pas, word ook uitgewys.

The present paper explores the range of issues confronted on undertaking research which sought to measure the speech intelligibility levels of a series of surgically-treated oral cancer patients each of whom spoke one of five South-Eastern Bantu languages (viz. Jacobson, 1986). The problem was approached by critically "dissecting" the notion of intelligibility in an effort to extract salient properties and, thereafter, by extrapolating applicable criteria of intelligibility measures to the set of phonetico-linguistic conditions characterising these languages. As such, the major concerns underlying speech intelligibility in the present paper are two-fold. The reconciliation of these two aspects forms the rationale for the choice of designated measures of intelligibility, and is represented in the materials themselves.

Nine members of the South-Eastern Bantu family of African languages are recognised and have developed as educational media and literary languages in South Africa (South Africa, 1985):

1. Nguni languages: Zulu, Xhosa, Swazi, and Ndebele, among a total of twelve Nguni languages.

2. Sotho languages: Southern Sotho, Northern Sotho and Tswana, among a total of eleven Sotho languages.

3. Tsonga.

4. Venda.

The present paper happens to deal with the Nguni and Sotho groups of indigenous languages, each of which is sub-divided to form dialect clusters. It was coincidental that the languages spoken by the randomly selected subjects of the study reflect the five most frequently spoken Bantu languages in South Africa, namely, Zulu, Xhosa, Northern Sotho, Southern Sotho, and Tswana.

In view of the number of dialects, some of which are poorly known, certain dialects have been raised to standard forms by taking into account various factors, such as the prominence of a

Die Suid-Afrikaanse Tydskrif vir Kommunikasieafwykings, Vol. 33, 1986 leader, or tribe size (Ziervogel, Louw, Ferreira, Baumbach \& Lombard, 1967). A second major feature of this group of languages is the profound multilingual situation which characterises speakers of the Bantu languages of South Africa.

No materials appear to have been published previously in the relevant African languages for the specific purpose of measuring intelligibility. Speech discrimination word lists used in audiology (e.g. Baragwanath Hospital, 1977) and phonetic inventories (e.g. Hillbrow Hospital, 1981) did not meet those requirements deemed fundamental to the study concerned, namely, clear evidence of the formulation of a set of criteria for item selection, taking into account previous research on intelligibility.

Speech intelligibility is the property of speech communication involving meaning, and is the quality or state of being comprehended or understood. A signal is intelligible to a listener, and for a speech signal to have intelligibility, both a speaker and a listener must be involved (Lehiste \& Peterson, 1959). Hence, because both speech production and speech perception are involved, distinctly more complexity is implied than is suggested by the use of superficially related terminology, such as articulation, recognisability, identifiability, and discriminability, which do not necessarily pertain to speech communication, consider meaning, or take full account of the listener.

Numerous factors determine this "communicative effectiveness". In the main, these are the social context, message content, the stimulus signal and the medium used for signal transmission, the speaker and his speech mechanism, and the characteristics of the listener. Speech intelligibility is employed by numerous disciplines (e.g. speech pathology, audiology, and acoustical engineering), each of which places differential emphasis on these major elements of the communication process. In the research on which this paper is based, the emphasis was on speaker characteristics with an attempt being made to control all other parameters as closely as possible, so that non-speaker parameters could serve 
largely as constants. Essentially, this paper seeks to determine Est in order to measure intity in a optimal message content in order to measure intelligibility in a valid fashion.

The outstanding feature of speech intelligibility is its performance The outstanding feature of speech performance (e.g. Yorkston and as an such, it supersedes several related criteria and models which capture a more limited scope. These include qualitative, perceptually-based tools used for differential diagnosis, (e.g. Darley, Aronson \& Brown, 1975), the evaluation of individual components of speech production, such as defective articulation (e.g. Prather, 1960), phonation, or resonance, and models which systematically evaluate the anatomical or physiological locus of disturbance along the vocal tract, such as the "point-place system" of Rosenbek and LaPointe (1978).

The inclusive nature of the concept of intelligibility is further exemplified by its pertinence to different speech-disordered groups (e.g. the cerebral palsied, alaryngeal speakers, cases of congenital orofacial malformations, among numerous others), despite the varying nature of the pathological elements of the speech production process. The concept of intelligibility is therefore sufficiently flexible to house a range of speech production variables, varying in combination and degree. It is thereby possible for each clinical population to bring to research its associated symptomatological milieu and still be investigated under the broad umbrella of intelligibility.

The potential information offered by intelligibility data is diverse, depending on both task selection and on the level of analysis undertaken: the more detailed the analysis, the richer and more versatile the applications of the data. In the literature, the analysis and presentation of intelligibility data assume a variety of forms:

1. Simple percentages of intelligibility reflecting the number of discrete units perceived correctly.

2. Analysis of perception-production confusions to form matrices (e.g. Nichols, 1976)

3. Analysis of the distance between produced and perceived phonemes (in words) in terms of distinctive features: manner, place or voicing differences.

4. Breakdown into analysis of vowel and consonant intelligibility, once the basic word intelligibility scores have been computed.

5. The determination of the patholect for a particular clinical population, or the pattern of phonemic confusions for a particular clinical group.

6. Combination of intelligibility measures with other measures such as speech rate, for example "Intelligible Words per Minute" (IWPM) and "Unintelligible Words per Minute" (UWPM) - Yorkston and Beukelman (1981).

7. Description of auditory or perceptual characteristics of the speech.

8. Development of a classification system for recognition of different groups demonstrating a particular speech disorder.

9. Development of an intelligibility measure which reflects severity of involvement such as Shriberg and Kwiatkowski's (1982) Percentage Consonants Correct (PCC), which is, however, defined as "a measure of articulatory proficiency".

Methods of assessment of surgically-treated oral cancer patients apparently sample the range of procedures generally employed in the examination of intelligibility in English-speaking pathological populations. The range of methods described in current and older research is extensive. However, whereas older research glosses informally through accounts of intelligibility, current research appears to aim at greater qualitative and quantitative specificity, with certain intelligibility materials even being designed for particular clinical populations and the ranges of severity within them.

Standardised word lists frequently constitute the materials of speech intelligibility assessment, e.g. the CID W.22 phonetically balanced (PB) word lists (Hirsh, Davis, Silverman, Reynolds, Eldert \& Benson, 1952), as employed in numerous studies (e.g. Skelly, 1973); the Consonant-Syllable Nucleus-Consonant words (Lehiste and Peterson, 1959), as selected and adapted by Tikofsky (1970), for example, for use with dysarthrics; the Fairbanks (1958) test of Phonemic Differentiation (a "Rhyme" Test), as used by Kipfmueller and Prins (1971), for example; the word lists of Black (1957), as used by Yorkston and Beukelman (1981), for example; and Moses' (1969) monosyllabic word lists (as cited by Nichols, 1976). Standardised sentence materials (e.g. the CID "Everyday Sentences") have also been utilised in examining the construct and criterion validity of various intelligibility procedures (Schiavetti, Metz and Sitler, 1981).

Finally, standardised phonetically balanced passages of reading, such as "My Grandfather", "The Rainbow Passage" and "Arthur the Rat", (Fairbanks, 1960), have been employed as elicitation material for intelligibility measurement (e.g. Platt, Andrews, Young and Neilson, 1978). However, the use of read material introduces a prerequisite of patient literacy, which was inappropriate in the research concerned. A further batch of materials includes those designed for specific clinical populations, such as the glossal and labial word lists for surgically-treated oral cancer patients (e.g. Skelly, 1973). In contrast, other research methods are individualistic from the viewpoint of the researcher, for example, the use of read sentences from early reading books in the case of deaf school-leavers (Kyle, Conrad, McKenzie, Morris \& Weiskrantz, 1978), picture description (Markides, 1978), and spontaneous speech samples (Weiss, 1978, cited by Schmidt, 1984). Under the latter circumstances, the properties of the spoken material are clearly far less stringently controlled.

As mentioned above, no similar spectrum of formalised materials exists in the languages under consideration. Nonetheless, within the above range, certain themes and issues pertaining to the choice and characteristics of materials recur with remarkable regularity, thereby illustrating the origins of useful criteria for devising appropriate intelligibility measures. These may be categorised in terms of three key components:

A. The composition of speech materials, which takes into account the message to be communicated, its length, complexity, and spontaneity.

B. The form of response required of the listener, in order that he may register his reaction to or understanding of the message, either by written or spoken means.

C. The choice of general procedural characteristics influencing the reliability and validity of the assessment, such as the manner in which stimuli are presented, and the selection of judges.

The first component, the composition of spoken materials, is the chief area of interest in the present paper. The second component extends beyond the focus selected for the present discussion. Only isolated aspects of the third component are relevant here: irrespective of the nature of the materials that are selected, or the manner in which the listener responds to the signal, the mass of methodological details pertaining to stimulus presentation and listener characteristics is largely independent of the language of the speaker and thus warrants routine consideration. Such factors 
include the decision to pre-record the speech stimuli or to present these live, whether to use the same stimuli repeatedly, the selection of suitable carrier phrases, and details of judge selection and training. Certain aspects of judge selection are, however, incorporated in the discussion below.

\section{KEY CONSIDERATIONS IN DEVISING APPROPRIATE MATERIALS}

\section{A. COMPOSITION OF SPEECH MATERIALS}

\section{UTTERANCE LENGTH}

While single words regularly form the basis of speech intelligibility scores, researchers frequently comment that singleword performance does not permit the evaluation of several critical parameters of speech, such as the effects of juncture, rhythm and stress patterns, and rate control (e.g. Griggs, 1958). Furthermore, the addition of context requires less fine discriminations of the listener (Miller, Heise \& Lichten, 1951). As such, there appears to be a demand for the development of formal materials suitable for studying the intelligibility of connected speech and its intrinsic prosodic properties. Towards meeting this need, Schiavetti, Sitler, Metz and Houde (1983) recently established two formulae for calculating contextual speech intelligibility on the basis of single-word intelligibility scores.

In spite of the above-mentioned criticism, Nichols (1976) reports that excellent correlations exist between PB scores and sentence intelligibility scores for esophageal speakers: ". . . hence, word intelligibility measures may be used as estimates of connected speech abilities with confidence". Hodson and Paden (1982) cite research with phonologically-impaired children demonstrating that essentially the same processes were revealed by single-word elicitation procedures as by both delayed sentence imitations, and by connected speech samples. This work therefore plays down, to some extent, the presumed effects of utterance length. Yorkston and Beukelman (1978) support the above findings noting that mean intelligibility scores for sentences were not different from scores derived from single-word tests. However, for transcription tasks, there was an interaction between severity and intelligibility scores on sentences versus words, that is, the most intelligible speakers tended to score higher on sentence transcriptions, while the least intelligible speakers received higher scores on single words. The same researchers also found that various measurement techniques, including both sentences and single words, tended to rank speakers similarly. Beukelman and Yorkston (1979) confirmed the close relationship between both single-word and sentence intelligibility, and the amount of information transferred between a speaker and a listener. Interestingly enough, Platt, Andrews, Young and Neilson (1978) concluded that intelligibility of PBs was an excellent measure for assessing speech competence after finding good correlations with assessments of the recognisability of individual phonemes.

It is clear, however, that the above correlations are mostly calculated on the basis of standardised English materials. As such, extrapolation of these results to other languages is uncertain. In summary then, the first issue encountered was whether to establish speech intelligibility levels based on single words and/or connected speech.

In view of the property of context, it is logical that connected speech would automatically reflect the semantic, morphological and phonological characteristics of a language. Therefore, the following discussion pertains chiefly to the development of singleword intelligibility materials, although a range of sociolinguistic characteristics of connected speech is highlighted simultaneously.
Furthermore, this review proceeds from overriding linguistic properties of the five languages, largely of a general, sociolinguistic nature - with implications at a semantic level, and progresses towards the enumeration of more specific, phonetic, phonological and morphological characteristics. All of these considerations affect the choice of individual word items.

\section{WORD FAMILIARITY/FREQUENCY}

A chief dimension along which word item selection for formal lists may be restricted, is that of vocabulary or work familiarity (e.g. CID W.22 word lists). Schultz (1964) examines the criterion of high familiarity of CID W.22 words, analysing the relationship between stimulus and response familiarity, and concludes that although the required educational level of the listener is lowered, certain unique patterns and problems arise (Schultz, 1964). Most researchers still agree, however, that the greater the frequency of the word, the more likely it is of being intelligible (e.g. Black 1952). This phenomenon has been explained in terms of "set" or "expectancy" (ibid. 1952).

In English, word familiarity is usually controlled by consulting Thomdike's list of word frequencies (1932, cited by Hirsh et al. 1952) or that of Thorndike and Lorge (1952, cited by Lehiste and Peterson, 1959).

In the African languages under consideration, only one study, of a most preliminary nature, has investigated word frequency per se (viz. Gowlett \& Rassmann, 1979), in one language. This study considers the 367 most common words in Southern Sotho, while Griesel (1979) lists common Zulu vocabulary items for instruction of learners of the language. Such research provides cursory guidelines regarding word frequency in African languages, and gives rough clues as to culturally relevant items in other Bantu languages. It appeared therefore that word familiarity was a significant consideration but its implementation would be constrained by the paucity of formal indices of word frequency. As such, this criterion would have to be borne in mind informally when formulating materials.

Several interrelated phenomena further complicate the application of the principle of word familiarity to South-Eastern Bantu languages, exerting their influences predominantly on the choice of vocabulary items appropriate for single-word intelligibility testing. These include the factors of multilingualism, vocabulary differences between urban and rural speakers of a language, mutual intelligibility in the face of dialectal variation, and the prevalence of borrowed words.

\section{a. MULTILINGUALISM}

A prime factor colouring the "purity" of the Bantu languages spoken by the subjects of the research under consideration, that of the judges, as well as native speakers who were consulted, is the phenomenon of multilingualism (e.g. Wilkes, 1978). This is a normal condition among black South Africans, particularly in the industrial cities and border areas, such as the Western Transkei, where Xhosa and Southern Sotho co-exist, and Eastern Transvaal, where Tsonga, Pedi and Zulu overlap (Lanham, 1978). In fact, in such multilingual communities, a "pure" Northern or Southern Sotho, Tswana, Zulu, or Xhosa speaker has long since disappeared, although a pure form of his language is still used in certain rural areas (Wilkes, 1978). Lanham (1978) cites the example that it is expected that an Nguni speaker will have a good control of a Sotho language if a substantial proportion of the immediate speech community speaks Sotho. 
One subject of the research under discussion, a nursing sister illustrates an apparently normal occurrence. She was raised and llukt speaking Southern Sotho, and married a Swazi speaker. After undergoing her professional training in Zulu, she moved to Port Elizabeth for a year and had to learn to speak Xhosa. She currently lives in a Zulu-speaking community in an East Rand curan area, delivers lectures in Zulu, speaks English at home to her husband, converses with other Sotho speakers in Zulu, but feels that her Zulu may be marred by a trace of Sotho "intonation": She also feels that after twenty-five years of speaking Zulu predominantly, her Zulu is better than her Sotho. This history presents a difficult decision in terms of the choice of language for administration of intelligibility tests. Finally, the inherent subjectivity of autobiographical reporting must be considered.

Subjects also claimed that whilst living in their townships surrounding Johannesburg, they had found themselves combining snatches of several languages. This would appear directly attributable to the multilingual milieu in such areas. Hence, it seems that in addition to possession of a language medium for education or rearing, there is an urbanisation of original, "pure" forms and the development of "city dialects".

The degree of this mixing, the levels on which it occurs, to what extent it takes place systematically and whether or not it differs from speaker to speaker and occasion to occasion, are but a few of the questions of which the answers can only be guessed at, for the simple reason that no researcher has as yet made any attempt to investigate these fields with their wealth of sociolinguistic phenomena (Wilkes, 1978: 110).

While on the one hand, there is the urban black demonstrating an extensive multilingual repertoire, there is on the other, the rural black with his associated vocabulary. In the study under consideration, the source of subjects covered both rural and urban areas, while judges were likely to be urbanised. As such, it was important to take both elements into account in compiling materials, by locating shared linguistic features and by avoiding both extremes as much as possible, so that all items were acceptable to both types of speakers.

\section{b. DIALECTAL VARIATION}

While all standards are to some extent idealisations, persistent difficulties arise in devising materials due to the prevalence of dialectal variation in the South-Eastern Bantu languages.

Although more than a dozen Bantu dialects have been investigated, many others have hardly been described. Far more than half of the dialects of which the Nguni and Sotho languages are composed, are as yet undescribed (Wilkes, 1978).

To what extent these dialects are (still) characterised by deviant or distinctive systems, or have had to make way for other (more dominant) systems, will become clear only when a comprehensive survey of all the South African Bantu language dialects is carried out (Wilkes, 1978).

In the practice of compiling word lists, it was difficult at times to know whether the native speaker being consulted was in fact speaking an unstandardised dialect or not. Furthermore, native speakers frequently disagree on lexical issues, and therefore, without actually consulting a vast range of native speakers, which was beyond the scope of the study, the information provided to the researcher had to be treated cautiously.

\section{c. BORROWED WORDS}

A further factor contributing to the difficulty of item selection for word lists is the influence of English and Afrikaans. In many dictionaries numerous entries representing such influences, are labelled "borrowed words". The large English-Afrikaans vocabulary of Sotho and the phonological principles by which loan words have been incorporated, have been described by Kunene (1963, cited by Lanham, 1978).

Van Wyk (1978) notes that English words were borrowed in the "educational, technical, commercial and industrial spheres", i.e. in those spheres where English is used extensively by blacks. Afrikaans loans on the other hand are drawn from practical spheres, such as clothing, farming, labour, household implements and foodstuffs. The ratio between English and Afrikaans loan words varies in the different languages, depending upon the proximity to either predominantly Afrikaans or English-speaking communities (Van Wyk, 1978)

In drawing up suitable lists of word items, the familiarity of borrowed words to the range of speakers of the relevant languages would be inestimable. Thus, unless these are extremely common, these should be omitted wherever possible in preference to more indigenous words. Conversely, in the urban areas speakers of non-standard varieties of the South-Eastern Bantu languages would find certain standard forms beyond even their passive lexical knowledge. It would therefore seem desirable to avoid selecting word items characterising either extreme, i.e. borrowed or esoteric indigenous words.

The methodological implications of the above factors for word familiarity complicate the task of devising single-word materials. considerably. Their recognition is nonetheless helpful in constraining the selection of word items along appropriate dimensions.

It is pertinent too to consider the control of word familiarity in direct relation to both listeners (judges) and speakers (subjects) For both groups it would be desirable that the language used for test administration is that spoken in the home during childhood, as well as that comprising the vernacular during schooling. Furthermore, in order to avoid the uncontrollable complications resulting from speaker unfamiliarity with word items, an auditory model for imitation should be provided by a proficient speaker of the language who is also familiar with the test materials.

The problematic influence of word familiarity, compounded by the fact that the subjects of the present research did not all speak the same language, could arguably be obviated through the use of a single, cross-linguistic task comprising nonsense words, additionally spanning a progression in phonetic complexity. Such a task would thereby tap phone recognisability, or, viewed differently, articulatory efficacy. However,

(i) such a task would be of limited clinical significance - the production of phonemic distinctions is of greater interest than the capacity for articulatory agility - which is linguistically meaningless;

(ii) it is most probably that only through production of linguistically meaningful units (i.e. words) that it can be established whether target phonemes are recognisable, in spite of phonetic distortion or allophonic variation;

(iii) linguistic variety within the subject sample was not sufficiently problematic that articulatory capabilities of subjects and inferences regarding articulatory functioning would be irretrievable.

\section{WORD LENGTH}

Single-word intelligibility materials in English have mostly com- 
prised monosyllables, as is evident from the original PB-50's (Egan, 1948), CID W.22 PB word lists (Hirsh et al. 1952) and the Fairbanks Rhyme Test (Fairbanks, 1958). This is perhaps due to the well-documented finding that the greater the number of syllables contained in an English word the more intelligible the word is likely to be (e.g. Black, 1952).

In the relevant African languages, monosyllables are comparatively infrequent. Therefore extracting the criterion of fewest possible syllables per word is perhaps inappropriate, as the effects of multisyllabic words on intelligibility may not be the same as in English. In the Nguni and Sotho languages, the criterion of monosyllabicity is virtually impossible to conform to as trisyllables and bisyllables, respectively, comprise the canonical forms of lexical items, while monosyllables are comparatively infrequent (Cole, 1955). (The canonical forms of lexical entries for Nguni verbs are frequently bisyllabic when constituting singular imperatives, but these items contain some undesirable redundancy, as is discussed later). Monosyllables are therefore insufficiently representative of the relevant languages to constitute an admissible criterion for the word structure of single-word intelligibility materials. Nonetheless, the reasoning behind the use of monosyllabic English words perhaps implies that words should have as few syllables as possible.

In the absence of verb prefixal and suffixal formatives, verb stems in the Nguni and Sotho languages are very commonly bisyllabic (CVCV shape). In the Nguni languages, this bisyllabic word structure represents the singular imperative form and some pronouns. In the Sotho languages, nouns also have a CVCV structure, whereas Nguni nouns mostly have a VCVCV structure due to the noun class prefix always beginning with a vowel. There are very few productive noun suffixes in the South-Eastern Bantu languages.

The Bantu languages are also syllabic tone languages (i.e. each syllable in a word has its particular tone value). The pattern of the syllable is mostly open, taking a $\mathrm{CV}$ form (consonant/consonant combination + vowel), but sometimes there is a no word-initial consonant (e.g. "a-ba-ntu": people - Zulu). In the Sotho languages it is not uncommoni to have a CVC syllable shape, where the final consonant is the syllabic nasal, $/ \sigma /$. The fact that the final consonant always has the same identity, is possibly a source of phonemic redundancy.

Taking into account the present considerations regarding word structure, it is apparent that Xhosa and Zulu vocabulary items of VCVCV form comprise nouns, while in the Sotho languages, the CVCV form demonstrates grammatical variety, including nouns, verbs and pronouns. From a grammatical point of view therefore the nature of bisyllabic Nguni words is more restricted than that of Sotho, and the exclusive selection of singular verb imperatives would add considerable redundancy to the stimuli in terms of both tonal cues and the identity of the final vowel, which would always be $/ a /$. However, the difference is not seen as significant because the phonological properties of the different word classes are homogeneous in major aspects, and are therefore of no specific interest.

The presence of syllabic liquids and nasals in the Sotho languages (e.g. $/ \mathrm{r} /$ and $/ \mathrm{m} /$ ) results in several words of a CV structure, which are bisyllabic, and words of a CVCV structure, which are trisyllabic (e.g. "rre" : father, "mmini" : dancer - Tswana). In view of the fact that such syllable structures are characteristic, these two forms would have to be included in the respective Sotho word lists.

\section{PHONETIC BALANCE}

The principle of phonetic balance, which probably embodies the most stringent form of the notion of "phonetic composition representative of the language" (Egan, 1948), dictates that the relative frequencies of occurrence of component speech sounds in a language, that is, their distribution in normal speech, should be reflected in any word list. In English PB materials, the phonetic composition (balancing) is based on Dewey's frequency count of English sounds in a sample of 100000 words (Dewey, 1923, cited by Egan, 1948).

Tobias (1964) states that phonetic balance is not a meaningful criterion for construction of word lists. He offers the rationale that Dewey's phonetic analysis of the relative frequency of English speech sounds was almost completely of written material. Tobias also observed "startling differences" in phonetic structure between any one PB list and any other. He states that although Egan's original PB-50 lists are not well-balanced phonetically, they are diagnostically superior to the CID W.22 lists in which the balance is far better. He concludes that since discriminationtesting based upon the PB-50 lists is useful, phonetic balance could not be playing much of a role. Nonetheless, the suggestion to consider the frequency of particular phonemes when devising materials, is pertinent.

No indices of phoneme frequency are known to exist in the relevant African languages. It would seem desirable nonetheless to represent all the phonemes in each language in order to access the manner in which these were articulated by subjects and perceived by judges. An arbitrary decision would be necessary regarding the number of times each phoneme should appear in the relevant word list.

Table 1: Consonant and vowel phonemes of five South-Eastern Bantu languages $\left(^{*}\right)$ combined with certain phonetic variants due to constitution of a cluster or nasal compound (C) or dialect (D). Abbreviations: Z. - Zulu; X. - Xhosa; N.S. - Northern Sotho; S.S. - Southern Sotho; T. -Tswana.

Z. X. N.S. S.S. T. 1 .

1. Bilagials

$$
\begin{aligned}
& 1 p^{\prime} / \text { - ejective stop } \\
& / p h / \text { - aspirated stop } \\
& \text { /b/ - murmured stop } \\
& \text { /b/ - voiced atop } \\
& \text { /B - implosive } a \text { top } \\
& \text { Im/ - nacal } \\
& \text { fmhl - murmured nasal } \\
& \text { (a) - glide } \\
& 1 \otimes / \text { - voiceless fricative } \\
& \text { /B) - volced fricative }
\end{aligned}
$$

2. LABIODENTALS

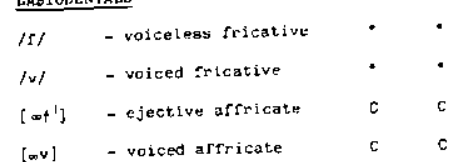




\begin{tabular}{|c|c|c|c|c|c|c|c|}
\hline & & & z. & $\underline{x}$. & N.S. & s.s. & $\mathrm{T}$. \\
\hline 3. & ALVBOLAF & & & & & & \\
\hline & $/ t^{\prime} /$ & - ejective stop & * & $\cdot$ & $\cdot$ & $\cdot$ & $\cdot$ \\
\hline & $/ t^{h /}$ & - aspirated atop & • & $\cdot$ & • & - & $\cdot$ \\
\hline & $/ d$ & - murmured atop & - & - & & & \\
\hline & $/ d$ & - volced stop & $\mathrm{c}$ & $\mathrm{c}$ & - & - & \\
\hline & 101 & - voiceless fricative & • & $\cdot$ & $\cdot$ & $\cdot$ & $\cdot$ \\
\hline & $|z|$ & - voiced fricative & - & $\cdot$ & & & \\
\hline & $/ 4$ & - lateral friestive & • & $\cdot$ & $\cdot$ & 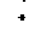 & \\
\hline & $/ b /$ & $\begin{array}{l}\text { - voiced lateral } \\
\text { fricative }\end{array}$ & - & $\cdot$ & & & \\
\hline & $/ n /$ & - nasal & - & $\cdot$ & • & • & - \\
\hline & Int/ & - murøured namal & & $\cdot$ & & & \\
\hline & $|r|$ & $-\operatorname{trill}$ & & & $\cdot$ & - & $\cdot$ \\
\hline & $/ 1 /$ & - lateral liquíd & - & $\cdot$ & * & - & - \\
\hline & $/ \mathrm{ti} /$ & - ejective lateral otop & $c$ & $\mathrm{c}$ & $\cdot$ & $\cdot$ & * \\
\hline & $/ t^{\mathrm{h} /}$ & - aspirated lateral stop & & & $\cdot$ & • & $\cdot$ \\
\hline & $/ \mathrm{d} y$ & - volced lateral affricate & $c$ & $\mathrm{c}$ & & & \\
\hline & $/ t_{0} \cdot 1$ & - ejective offricate & - & - & • & • & $\cdot$ \\
\hline & $/ t_{B}{ }^{n} /$ & - appirated affricate & & - & + & • & $\cdot$ \\
\hline 4. & $\underline{\text { LABIO-A }}$ & ALVEOLAFS & & & & & \\
\hline & $\mid \oplus \mathrm{s} /$ & - fricative & & & $\cdot$ & & \\
\hline & 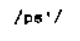 & - ejective affricate & & & • & & \\
\hline & $/ \mathrm{pa}^{\mathrm{h} /}$ & - abpirated "double" & & & $*$ & & \\
\hline s. & ALVEOPA & ALATALS & & & & & \\
\hline & /1 & - voicelebs fricative & - & $*$ & • & - & - \\
\hline & $|3|$ & - volced fricative & & & $\cdot$ & & \\
\hline & $\ln l$ & - nesal & - & $\cdot$ & • & - & $\cdot$ \\
\hline & $/ \mathrm{ph} /$ & - murmured nagal & & $\cdot$ & & & \\
\hline & $/ \mathrm{j} /$ & - g11de & - & $\cdot$ & $\cdot$ & - & $\cdot$ \\
\hline & $/ t \int^{n /}$ & - aepirated affricate & & $\cdot$ & $\cdot$ & & $\cdot$ \\
\hline & $/ t 5 /$ & - eject1ve affricate & - & $\cdot$ & • & $\cdot$ & $\cdot$ \\
\hline & $/ d y$ & - murmured af fricate & * & $\cdot$ & & & $\cdot$ \\
\hline & $/ d y /$ & - volced affricate & $\mathrm{c}$ & $c$ & & & - \\
\hline
\end{tabular}

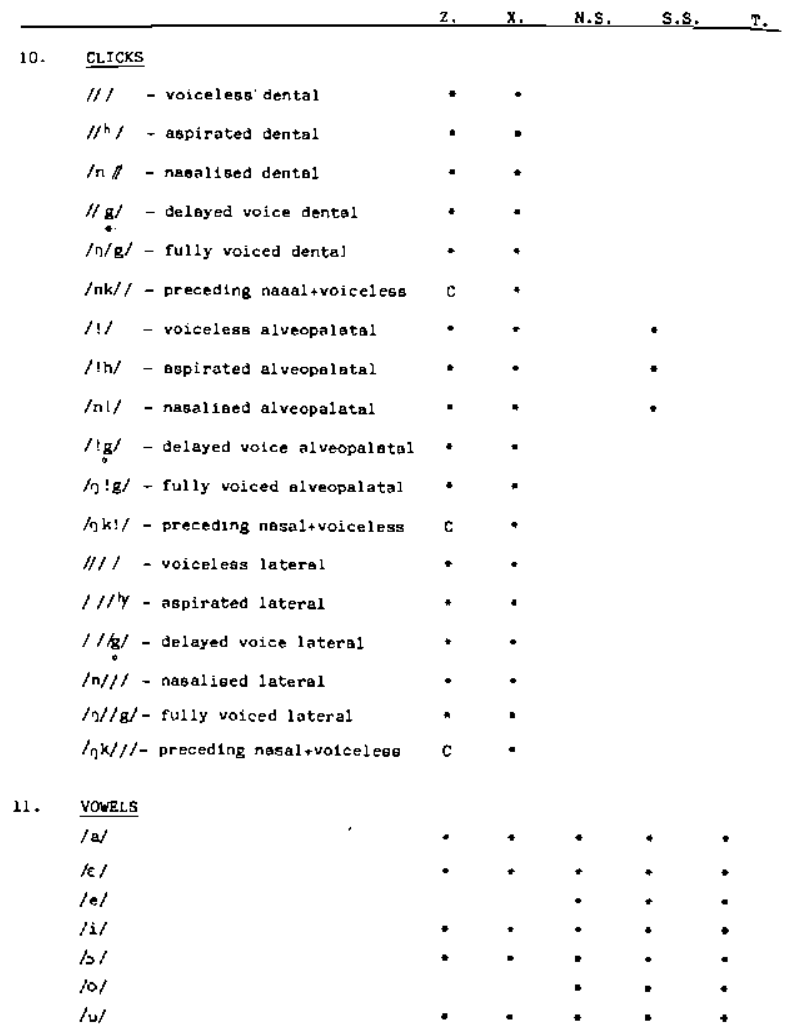

Table 1 contains the phonemic inventories of Zulu, Xhosa, Northern Sotho, Southern Sotho and Tswana, based on the works of Brown (1971), Cole (1955), Doke (1931), Doke and Mofokeng (1957), Jordan (1966), Khumalo (1981), Mabille and Dieterlen (1961), Ziervogel et al. (1967), Ziervogel, Louw and Taljaard (1981), and Ziervogel and Mokgokong (1975). These inventories are presented in order to identify the phonemic constituents of the South-Eastern Bantu languages and to informally observe differences from English. To capture subtle phonetic differences between ostensibly similar articulations belonging to different languages (e.g. /b/ in Zulu as compared to the Sotho languages), finer phonetic specifications are incorporated within the phonemic description (viz. /b/ versus /b/: murmured versus voiced $/ \mathrm{b} /$ ).

The purpose of depicting certain phonetic variants, comprising members of consonant clusters or nasal compounds; is that clusters are particularly complex and therefore most taxing phonetically - quite conceivably affecting intelligibility. For this reason they would add an additional dimension of complexity to intelligibility word lists. In Table 1 elements of clusters or nasal compounds are marked with a " $\mathrm{C}$ ".

Dialectal variants are incorporated in Table 1 too, primarily to mark alternative correct productions which could be misconstrued as errors, and for the sake of completeness. These are marked with a " $\mathrm{D}$ ". In conducting a single-word intelligibility task, dialectal variation would need to be taken into account and should not incur penalty. For example, in Northern Sotho, the labio-alveolar fricative, $/ \Phi \theta /$, may also be produced as $/ \mathrm{A} / \mathrm{g}$, or $/ \mathrm{h} /$, or $/ \mathrm{f} / \mathrm{)Ziervogel}$ et al. 1967).

Certain segments appear only within ideophones in the canonical forms cited above. An ideophone is an onomatopoeic word form with its own morphology, phonology and prosodic rules (Kunene, 1978). In view of these properties, the controversial definition of ideophones (Wilkes, 1978), and their frequent appearance within a particular grammatical structure, such as "ho re ..." (Southern Sotho), from which it may be indivisible, it would seem unwise to consider ideophones as word items. This view would hold irrespective of whether an ideophone contained a required phoneme. 
The extensive range of consonants in each of the above languages compared to English, has implications for the length of word lists it would be desirable to include all consonants more than once for reliability purposes.

Comparison of the phonemes of Zulu, Xhosa, Southern Sotho, Northern Sotho and Tswana, reveals language-specific trends (Table 1): the vast repertoire of clicks, voiced and voiceless fricatives, $/ 2 /$ and $/$, and murmured forms of $/ b /, / d /$, and / are characteristic of Zulu and Xhosa. Xhosa also has an extended range of palatal phonemes, depicted orthographically as "ty" and "dy", and the ejected velar affricate $/ \mathrm{kx} /$. In addition many Zulu fricatives are pronounced as affricates in Xhosa, for example, "inhloko" is "intloko", and "insimu" is pronounced "intsimi".

Particular to the Sotho group of languages are the alveolar trill, $/ \mathrm{r} /$, the aspirated lateral stop, $/ \mathrm{tlh} /$, the voiced alveopalatal fricative, $/ 3 /$, and the labio-palatal "double" phonemes (affricate-like, generally characterised by two virtually simultaneous, non-adjacent places of articulation), $/ \mathrm{p} \zeta /, / \mathrm{p} \% /, / \mathrm{psh} / \mathrm{s}$ and $/ 03 /$. Members of the latter group tend to be dialectal in Tswana. Characteristic of Northern Sotho are the labio-alveolar phonemes, $/ \mathrm{sg} / \mathrm{f} / \mathrm{ps} / \mathrm{i}$ and $/ \mathrm{psh} /$

Tswana contains marked dialectal variation, which influences the production of alveolar and alveopalatal affricates, and also leads to the non-lingual voiceless fricative also being produced as either $/ \mathrm{f} /$ or $/ \mathrm{h} /$.

All five languages display phonemic aspiration, ejection of consonants, and the palatal nasal phoneme, $/ \mathrm{s} /$. As a group these therefore show a variety of airstream mechanisms in speech: glottalic ingressive and egressive, velaric, as well as pulmonic airstream mechanisms.

Where vowel phonemes are concerned, South-Eastern Bantu languages have five to seven pure vowels as a rule, no central vowels, and no diphthongs. The Nguni languages, Xhosa and Zulu, both have five basic vowel phonemes with one variant each of $/ e /$ and $/ o /$, acting in complementary distribution as a result of adjacent vowel influence. The Sotho languages, Southern Sotho, Northern Sotho and Tswana, have seven basic vowels and four additional phonetic variants (Ziervogel et al. 1967).

\section{B. RESPONSE FORMATS}

The formalised materials discussed above require that the listener's response consists of repetition, transcription, written completion of a word with one letter, or completion of multiplechoice response formats. It would appear though that transcription or stimulus repetition serves as the closest means of reflecting the listener's actual perceptions. Although multiplechoice formats have excellent quantifiability and recognised usefulness, analysis of such tasks indicates that these may well test identifiability rather than intelligibility. The listener's "perceptions" are structured to fit a particular framework and real perceptions may be ignored. Furthermore it has been demonstrated that multiple-choice response formats may be graded in difficulty by systematically altering the information provided to the judges, while keeping the stimulus constant (Yorkston \& Beukelman, 1980). In this instance there is an inverse relationship between the number of selection options and intelligibility (ibid.). The influential effects of various response formats with specified options suggest that these may contaminate the results of intelligibility tests and are best avoided.
Where test materials comprise connected speech, rating scales are commonly used to capture gradations of speech intelligibility. These clearly demand a different type of subjectivity to that of the procedures described previously, in that they rely on appraisals rather than the listener's actual comprehension of speech. However, the appropriateness of different rating scales deserves judicious consideration to ensure the selection of valid indices of speech intelligibility (cf. Schiavetti, Metz \& Sitler, 1981).

Many of the issues concerning response formats are examined by Yorkston and Beukelman (1978). These researchers conclude that it may be beneficial to take advantage of the task hierarchy that apparently exists among quantification procedures, instead of relying on a single measurement technique to quantify speech across the entire performance range. However, this suggestion would appear more suited to clinical practice than research, as in the case of the latter, a standard methodology is necessarily implemented.

\section{THE NATURE OF REDUNDANCY}

The foregoing discussion reveals various factors which could increase the redundancy of the speech signal during intelligibility testing. These include the offer of options in identifying stimulus words, the use of linguistic context, the exclusive selection of singular verb imperatives, and an increase in the number of syllables per stimulus word (certainly for English). However, redundancy in a word intelligibility task is an undesirable feature in that it meddles with the attempt to measure "absolute" intelligibility. Meyerson, Johnson and Weitzman (1980) comment on the contribution of redundancy to the intelligibility glossectomees, reporting a 50 per cent discrepancy in intelligibility scores based on single words versus connected speech.

In the present South-Eastern Bantu languages, there is likely to be some degree of redundancy in single words existing independently of that contained in connected speech, largely due to the multisyllabic, tonal nature of words in these languages. As such redundancy is potentially introduced at the word level in the form of semantic and grammatical tonal cues. These properties, in conjunction with fairly consistent syllable shapes and sequences, conceivably provide supplementary cues to single-word intelligibility stimuli.

On a morphological level, furthermore, many single words in the Bantu languages are polymorphic, with all prefixes and some suffixes showing grammatical tone. In this regard, it is noteworthy that in Zulu, for example, noun prefixes are composed of only three vowels and seven consonants (Westphal, 1973). This limited range could possibly aid the listener's decision when the noun stem is doubtful. On the other hand, noun stems are so varied that it is uncertain whether the class prefix effectively contributes any redundancy to the speech signal, in spite of its tonal characteristics and phonetic composition. It would seem, nonetheless, that if grammatical tone does add redundancy to work items, this would operate in the case of nouns predominantly.

In attempting to eliminate all the above-mentioned potential sources of redundancy in a word intelligibility task, the syllable composition of the words would probably need to be restricted to being as short but as representative as possible, the noun class prefix would have to be limited to only one syllable, and the use of options in the response format would be rejected.

\section{CONCLUSION}

A detailed account has been presented of paramount considerations in resolving the issue of task and material selection 
for the measurement of intelligibility in five South-Eastern Bantu languages. The final outcome of the effort to attain maximally valid measures was therefore arrived at under the following restrictive circumstances:

1. the absence of a Dewey-type index of relative phoneme frequency;

2. the absence of a Thorndike-Lorge-type index of word frequency for languages other than Southern Sotho;

3. the absence of standardised passages of reading;

4. the paucity of intelligibility materials for English-speaking glossectomees to act as guidelines for the development of materials in African languages.

The decision was made to couple two complementary tasks: a single-word task, which may be viewed as a "molecular-intensive" or detailed analytical measure, while rating of a spontaneous speech task comprises a "molar-extensive" or global measure (Hollenbeck, 1978), and may be regarded as a "molar taxonomy", as it combines a "a number of features, actions, directions, and objects of behaviour" (Sackett, 1978: 25). This decision was determined by three factors which receive elaboration below: the specific research objectives, the emergency of two distinctive genres of intelligibility measures, and the limitations of any single measure of intelligibility in isolation.

Firstly, in considering the purpose of the research, there was dual interest in "how well speech was understood", which indexes overall speech effectiveness, as well as in specific error patterns. It seems logical that there be an underlying commonality to both processes and one would predict that the number of errors relates closely to the understandability of contextual speech. However, two discrete tasks were deemed necessary: it could not be assumed that the percentage word intelligibility based on unstandardised materials would accurately parallel the level of spontaneous speech intelligibility; neither could it be assumed that a word list, assembled on the basis of strict criteria such as phoneme position and syllable structure, would reflect the properties of everyday speech and vocabulary. The use of spontaneous speech samples was therefore important for the criterion validation of an unstandardised work intelligibility task.

Hence, a word intelligibility task incorporating the phoneticophonological properties of the relevant language was desirable in that

1. phonemes could be included in a controlled and structured manner;

2. the lack of context normally provided by syntax would allow evaluation of each phoneme in a minimally redundant form;

3. a numerically specific index of the percentage of intelligible words could be computed;

4. words are the work-horse of intelligibility materials in English, and serve as highly accessible units of speech for a researcher who is not a fluent speaker of a foreign language.

Similarly, a spontaneous speech task was desirable in that

1. ratings of performance on such a task could tackle the construct of speech intelligibility directly as everyday connected speech would be typified, providing a reasonable approximation of the normal communication process;

2. the task promotes the linguistic style and vocabulary of the subject and thereby captures a congruent communicative whole. Isolated words, in contrast, are in danger of falling peripheral to either the judge's or the subject's vocabulary, despite careful item selection.

The particular method whereby spontaneous speech samples may be evaluated, constitutes a separate methodological decision which lies outside the scope of the present paper.
The lists of single words in Zulu, Xhosa, Northern Sotho, Southern Sotho and Tswana, appear in Appendixes 1-5. As far as possible, these were formulated and items selected according to the following criteria:

1. Vocabulary items should be familiar to both rural and urban speakers of the relevant language.

2. The word structure should be highly representative of the particular language in question. A scan of common vocabulary items in Nguni and Sotho languages, combined with the notion of shortest word having least redundancy, suggested that it was most appropriate to include bisyllables in the Sotho languages where the simplest uninflected nouns and verbs have a CVCV (nasal) structure, and trisyllables in the Nguni languages where nouns of a VCVCV structure predominate because of the pre-prefix. Although CVCV verb imperatives are readily available in the Nguni languages, the final $\mathrm{V}$ is always $/ \mathrm{a} /$ which acts to increase the redundancy of stimuli in that the final vowel is always given.

3. All consonant phonemes in each language should be included twice in the list, once as the first consonant in a word and secondly, in an intervocalic position.

4. Within the scope of these criteria, the number of items presented to the judges was restricted to as few as possible by eliminating the least satisfactory items. This represented an attempt to increase both reliability and validity. The least satisfactory items in the research were those of doubtful conversational familiarity. It was hoped that the remaining items would constitute sufficiently long tests and that these would be more reliable, comprehensive and valid than lists that would have been any shorter.

5. Rigorous balancing of vowel phonemes was not undertaken due to the stringency of primary requirements already mentioned. An attempt was made, however, to keep the frequency of different vowel phonemes equivalent within each word list.

Secondly, the above exposition of intelligibility and related issues reveals two distinguishable categories of assessment methods: the first category, comprising formalised procedures, displays a certain stringency of both item selection (the maximal units of which are sentences), and procedural design (which facilitates quantification and error analysis). However, English procedures of this nature are at times of questionable validity, in terms of the definition of intelligibility provided earlier in this paper, as these could be more accurately regarded as exercises in stimulus discriminability. In the case of South-Eastern Bantu languages, materials of this nature could be formulated through the informal application of principles such as word familiarity, word length, and phonetic balance.

In contrast, less formalised procedures, in that either the material or the assessment procedure itself is irregular, perhaps represent more valid appraisals of intelligibility. These procedures generally have, as a minimal unit, the sentence, and usually consist of either read or spoken samples of connected speech. Hence, these demonstrate high face validity in representing overall speech behaviour, which is of prime interest. However, in this instance, the validity of the listener's task or tool of judgment may be questionable in relation to the construct of speech intelligibility

These observations suggest that both formal and less formal procedures have merits and demerits, and probably represent complementary entities, which are most effective in unison.

Thirdly, as demonstrated by English materials, although the above range of intelligibility measures and procedures is vast, in most cases, only a portion of overall speech performance is 
captured by a single measure, which furthermore, cannot be employed to describe performance across the entire severity range: as all measures have both a ceiling and a floor effect, these are sensitive to performance changes in only a limited range.

These limitations underscore the strength of any single measure of intelligibility in research which is combined with at least one other intelligibility task, or the event of intelligibility comprising only one measure within a battery of measures of speech production, where such a battery also incorporates acoustic, articulatory, and physiological studies. Additional measures then serve as concurrent validation procedures.

If "the observer's perception and subsequent judgment represents the final validity for the identification and measurement of disordered speech" (Young and Downs, 1968: 6), the present paper comprises a preliminary step in the direction of reflecting this criterion, that is, intelligibility, among speakers of SouthEastern Bantu languages.

\section{ACKNOWLEDGEMENTS}

The Human Sciences Research Council, Pretoria, and the Senior Bursary Fund, University of the Witwatersrand, Johannesburg, are gratefully acknowledged for their generous financial support of the doctoral research on which this paper is based.

\section{APPENDICES}

APPENDIX 1 : ZULU WOAL LIST

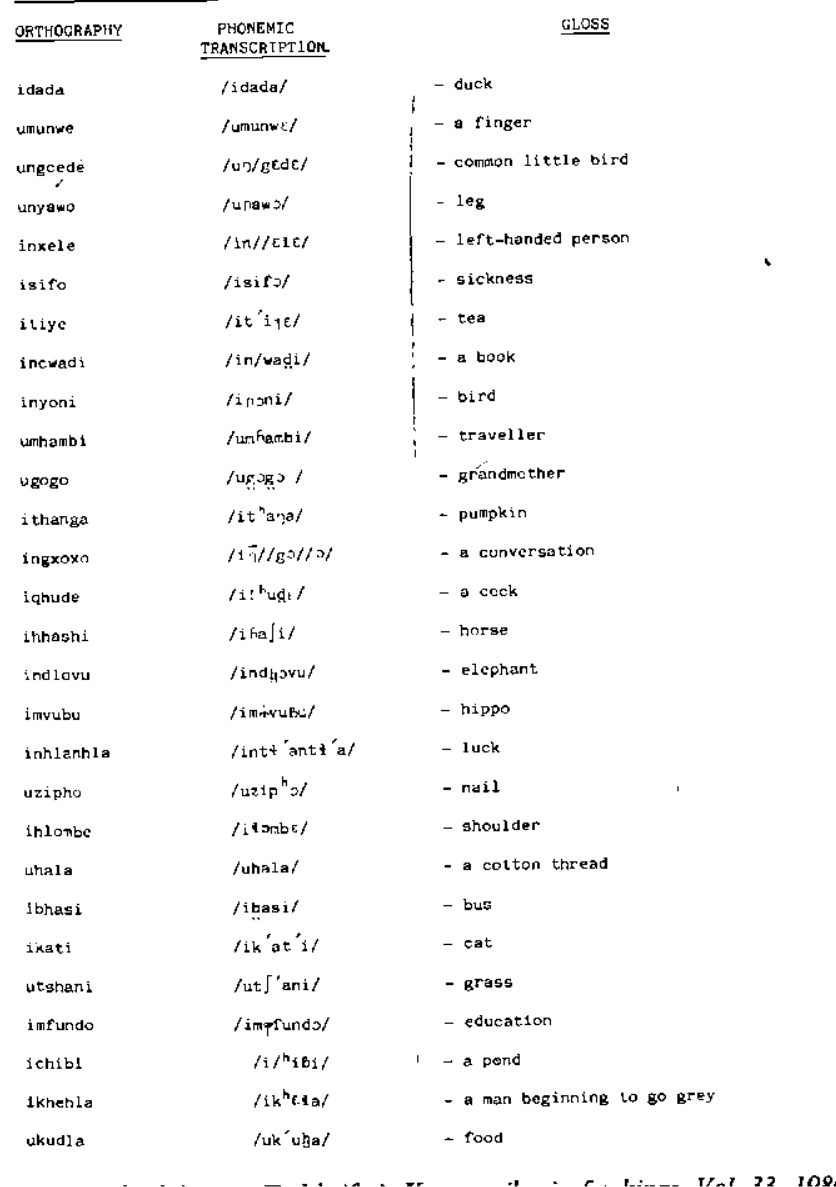

\begin{tabular}{|c|c|c|}
\hline ORTHOGRAPHY & $\begin{array}{c}\text { PHONEMIC } \\
\text { TRANSCRIPTION }\end{array}$ & GLOSS \\
\hline innlanzi & /intt'andzi/ & $-f i s h$ \\
\hline igazi & /1gaz1/ & - blood \\
\hline ixhegu & $/ \mathrm{i} / / h_{\mathrm{r}} \mathrm{gu} /$ & - old man \\
\hline iqanda & /itanda/ & - an ese \\
\hline umeqo & fume:s/ & - a jump \\
\hline izinyo & fizipos/ & - tooth \\
\hline insimu & /ints'imu/ & - field \\
\hline uqhotro & $/ u !^{n} 3 t^{n} \cdot y$ & - snrivelled thing: homeless person \\
\hline ufudu & fufudu/ & - tortoiac \\
\hline iviki & /ivik'i/ & - weck \\
\hline iphepna & $/ \mathrm{p}_{\mathrm{p}}^{\mathrm{h}} \cdot \mathrm{p}_{\mathrm{h}}^{\mathrm{h} /}$ & - paper \\
\hline iconsi & /i/onts'if & - drop of liquid \\
\hline unpompi & /ump 'smp'if & - a tap \\
\hline igeja & $\mid \mathrm{ig} \cdot \mathrm{d} z \mathrm{z} /$ & - a plough \\
\hline izinvis & /iziduuf & - shcep \\
\hline umgqomo & tun! g.m. $m /$ & - barrel; drum: "round peraon" \\
\hline imbuzi & /imbuzi/ & - goat \\
\hline iwashi & /iwajis & - a vatch \\
\hline indlebe & /ind br.br/ & - ear \\
\hline idlelo & $/ 1 \mathrm{kn} 1 \mathrm{~d} /$ & - paature \\
\hline induku & /induk $\mathrm{u} /$ & - a stick \\
\hline umbhado & tum $\int \mathrm{adg}$. & - a wedding \\
\hline inantsh1 & /nant $\int^{\prime} i /$ & - naertjic rruit \\
\hline il anga & /ilana/ & - sun; day \\
\hline inzule & /Indzule/ & - type of 1ndigenous cou \\
\hline i jaha & /id zạaha/ & - strapping fellor \\
\hline amakha & famak $\mathrm{h}_{\mathrm{a}} /$ & - perfume, scent \\
\hline ingial & /inils/ & - lazy pereon \\
\hline isiklabhu & flsiks 'abuf' & - sheep \\
\hline igceke & /i/gtik'r/ & - courtyard \\
\hline ingaondo & /in!gonds/ & - mind; brain \\
\hline чхамц & $/ u / / a m u /$ & - leguaan \\
\hline ig $\times$ athu & $/ \mathrm{i} / / \operatorname{ggat}_{\mathrm{g}} \mathrm{bu} /$ & - stride $(n)$ \\
\hline ing $\times$ ang $\times a$ & $/ \mathrm{in}_{\mathrm{g}} / / \mathrm{gar}_{\mathrm{g}} / / \mathrm{g} \mathrm{g} /$ & - a green-striped frog \\
\hline igxolo & $/ \mathrm{i} / / \mathrm{g} \cdot \mathrm{s}+\mathrm{s} /$ & - bark of tree \\
\hline icici & $/ \mathrm{i} / \mathrm{i} / \mathrm{i} /$ & - earring \\
\hline ірара & /ip'ap'a/ & - porridge \\
\hline \multicolumn{3}{|c|}{ APPERUIX 2 : XHOSA WOAD LIST } \\
\hline ORTHOGRAPHY & $\begin{array}{c}\text { PHONEMIC } \\
\text { TRASSCRIPTIOS }\end{array}$ & $\underline{\text { GLOSS }}$ \\
\hline inzala & /indzala/ & - progeny; interest (on capital) \\
\hline indlovu & /indp̣pvu/ & - elephant \\
\hline indyebo & Infeest & - treasure; plenty \\
\hline ityhefu & $/ i c^{t} \cdot f u t$ & - poison (n) \\
\hline intyelo & tinc'rist & - information \\
\hline intlahla & /intz'ata/ & - shiny, glossy appearance \\
\hline ibhokwe & /igolowit & - goat \\
\hline iraru & /ixaru/ & - tax, hut-tax, pol1 tax \\
\hline igronya & $/$ i, 2 ก) & - sack-cloth, coarse cloth; sack \\
\hline 1krele & $/ 1 \mathrm{kx}^{\prime} \mathrm{Cl} \mathrm{a} /$ & - stabbing assegal, sword, sickie \\
\hline inashe & /thaje/ & - horse, mount; abcess \\
\hline imvubu & 1mavubu/ & - hippopotamus \\
\hline indoda & /ind ada/ & - man, husband \\
\hline Intaimi & /nnts'imil & - arable field, garden \\
\hline imfene & /impre 'ene/ & - baboon \\
\hline amanzi & /amandzi/ & - vater \\
\hline ikhaya & $/ \mathrm{ikh}_{\mathrm{a}} \mathrm{a} /$ & - home, residence, dwe11ing, domic1le \\
\hline ityiphu & $/ 1 c^{\prime} \mathrm{ip}^{\mathrm{h}_{\mathrm{u}} /}$ & - domestic fow 1 \\
\hline isidlu & $/$ isiggy/ & - meal, reast \\
\hline ikratshi & fikx'at $\int^{\prime}$ is & - arrogance \\
\hline i therga & intana/ & $\begin{array}{l}\text { - pumpkin: thigh; outpasture; outfarn. } \\
\text { outkraal }\end{array}$ \\
\hline ubigi & /ubizil & $-($ sweet $)$ milk \\
\hline
\end{tabular}




\begin{tabular}{|c|c|c|}
\hline ORTHOGRAPHY & $\begin{array}{c}\text { PHONBWIC } \\
\text { TRRNSCRIPTION }\end{array}$ & 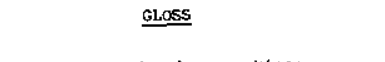 \\
\hline icict & $/ 1 / 1 / 1 /$ & $\begin{array}{l}\text { - something circular: earring: } \\
\text { small group }\end{array}$ \\
\hline ixesha & /i $/ /$ E $: \mathrm{a} /$ & - time, period; wateh, clock \\
\hline ucango & fu/apst & $\begin{array}{l}\text { - door (not a doorway); cell in a } \\
\text { honeycusb }\end{array}$ \\
\hline incoka & /in/מk's/ & - conversstion \\
\hline ixhego & $/ 1 / /^{h} \in \boldsymbol{g} J /$ & - old men \\
\hline igaira & $/ \mathbf{i} \lg _{0} \mathrm{i} \times \mathbf{x} /$ & - doctor, medicine-man, witch-doctor \\
\hline ingxowa & $/ \mathrm{i} y / \mathbf{g} \mathrm{g} \mathbf{w a} /$ & - bas, pouch, sack, pocket \\
\hline umfundi & /umprondi/ & $\begin{array}{l}\text { - pupil, scholar, reader, disciple, } \\
\text { student }\end{array}$ \\
\hline izonika & $/ 1201 \mathrm{k}^{\prime} \mathrm{a} /$ & - Loaves of bread \\
\hline iphepha & fiphepha/ & - paper; page \\
\hline uluvo & /ul uvs/ & $\begin{array}{l}\text { - feeling, senaation: vies, opinion: } \\
\text { impression }\end{array}$ \\
\hline Ingcambu & /17/gambu/ & - root \\
\hline impompo & fimp'smp's/ & - pump \\
\hline 1qhosha & $/ i+h 0 \int a /$ & - buttan, buckle; coin; seashe11 \\
\hline ubhaqo & fubelof & - diacovery \\
\hline ibuzi & /1Buzi/ & - rat \\
\hline Lcebe & $/ 1 / \varepsilon t_{a} /$ & - councillor; splinter \\
\hline i jokve & 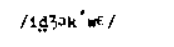 & - jar \\
\hline ugcado & $/ u / g$ ad $3 /$ & - a roset \\
\hline uvuyo & $/ \operatorname{luvu}\lrcorner z$ & - joy, Bladnesa, rejoicing \\
\hline ivatahi & /iwat!'is/ & - watch, clock \\
\hline inlobo & $/ i \neq 3 B+/$ & - suraner \\
\hline itsh1ntshi & $/$ it $\int^{\prime}$ int $l^{\prime}$ i/ & - change $(n)$ \\
\hline utolo & /ut's12/ & - arrow \\
\hline idana & /ị̣ngma/ & - dem, regervolr \\
\hline inyos 1 & /inosi/ & - bee \\
\hline isinge1 & /isinegif & - mane \\
\hline ushenxo & $/ \mathrm{u} \int \mathrm{En} / / \mathrm{o} /$ & - leeway \\
\hline udladla & /ubąa/ & - granary \\
\hline ingwla1 & $/ 1$ poritis & - a gulp, swallow \\
\hline igatya & $/ \mathrm{igac} \cdot \mathrm{a} /$ & - clause: branch \\
\hline unhambi & Jumfambi/ & - traveller \\
\hline 1qands & / $\mathrm{S}$ !anda/ & - eBg: large bead \\
\hline ichibi & $/ i^{h_{1}} r_{\text {in }} /$ & - pool, pord, lake \\
\hline Igxalaba & /i//galefa/ & - shoulder, shoulder-blade \\
\hline Inxele & $/$ in $/ / \varepsilon 1 \varepsilon /$ & - left handi left-handed person \\
\hline umnquaz 1 & /unn 1 & - cap, hat \\
\hline ingwanqua & /n!man!a/ & - step \\
\hline icangci & $/ \mathrm{i} / \mathrm{a} \nabla / \mathrm{gi} /$ & $\begin{array}{l}\text { - piece of corrugated iron; metal } \\
\text { gheet }\end{array}$ \\
\hline inkeazo & $/ 1 \pi \mathrm{k} / \mathrm{az} \mathrm{y}$ & - memorandum; explaration \\
\hline uncipho & $/$ un $/ \mathrm{ip}_{\mathrm{p}} \mathrm{H}_{\mathrm{J}}$ & - decline, decrease \\
\hline Inkrwaleko & $/$ ink/ $/$ walk k's/ & - mleery \\
\hline ungrgqueho & 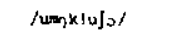 & $-\operatorname{ann}$ \\
\hline 1ngqumbo & /inlgumba/ & - anger \\
\hline $\ln \rfloor \operatorname{in} 1$ & /indsinil & - engine \\
\hline 1 jaj1 & $/$ idzad 31/ & - Judge \\
\hline unge $\ln 1$ & /un/g̣in1/ & - one vho keeps \\
\hline ungod1 & /ung $x$ dis/ & - deep excavation, mine; a hole \\
\hline Ingoz1 & $/$ ing.zil & - danger; misfortune, accident, injury \\
\hline inkqu & $/ 1 \mathrm{~g} k 1 \mathrm{u} /$ & - reality \\
\hline unogho & $f$ unoth $\mathrm{h}^{\mathrm{h} /}$ & - clothes-peg \\
\hline iaixa & $/ \mathrm{isi}^{\mathrm{si}} / / \mathrm{a} /$ & $\begin{array}{l}\text { - bunch; handfu1 (or grasa, corn } \\
\text { flowerg) }\end{array}$ \\
\hline ungweb1 & /UmBvEBi/ & - those who judge \\
\hline \multicolumn{3}{|c|}{ APPENDIX $3:$ : NORTHERN SOTHO WORL LIST } \\
\hline taebe & $/$ ts $s^{\prime}$ ebe/ & - ear \\
\hline pudi & $/ p^{\prime}$ udi/ & - goat \\
\hline d1jo & $/ d i z o l$ & $-f o o d$ \\
\hline
\end{tabular}

\begin{tabular}{|c|c|c|}
\hline ORTHOGAAPHY & $\begin{array}{c}\text { PHONBMIC } \\
\text { TRArSCRIPIION } \\
\end{array}$ & $\underline{\text { GLOSS }}$ \\
\hline noka & /nok'a/ & - river \\
\hline kgogo & /kx'orof & - chicken \\
\hline topa & $/ t^{\prime}$ ops/ & - pick up \\
\hline toro & tars/ & - drcami prickly pear \\
\hline bjala & /Bzala/ & - plant; beer \\
\hline botse & /onts'e/ & - beautiful \\
\hline ngaka & / gak'a/ & - doctor \\
\hline mong & $/ m a n$ & - maater, omer; one, other (adj.) \\
\hline nyale & /nola/ & - to marry, give dowry \\
\hline tăea & $/ \mathrm{t} \int^{\prime} \mathrm{ea} /$ & $\begin{array}{l}\text { - take, recelve, get hold, take on; } \\
\text { marry }\end{array}$ \\
\hline hlogo & ftors/ & - head \\
\hline tlala & $/ \mathrm{t}^{\prime} \mathrm{e}$ ala $/$ & - hunger \\
\hline khuta & $/ k^{\text {hut }}$ 'af & - hide \\
\hline phiri & $/ \mathrm{p}^{\mathrm{h}_{\mathrm{iri}} /}$ & - пуела, 凶olf \\
\hline motho & /mothof & - person \\
\hline pshaptha & $f p \int_{\text {hap }} \int_{\text {haf }}$ & - applaud, clap \\
\hline tŏhipi & $/ \mathrm{tJ}^{\prime} \mathrm{ipi} /$ & - iron; be11 \\
\hline thaba & $/ 1^{\text {haba/ }}$ & - Blaughter, to stab a persor \\
\hline psinya & /ps'ina/ & - defaecate! \\
\hline holle & /folle/ & - to cry \\
\hline dinku & $/ d i f k^{\prime} u /$ & - sheep \\
\hline ngwana & /imana/ & $-\operatorname{crilid}$ \\
\hline motse & /mots'e/ & - v1llage, town \\
\hline กroši & halis & - alone \\
\hline tăhuene & $/ \mathrm{t} \int$ 'vene/ & - baboon \\
\hline mmele & /here/ & - body \\
\hline mpa & $/ h_{p}{ }^{\prime}$ a/ & $\begin{array}{l}\text { - stomach; skipping rope; sky between } \\
\text { two clouds }\end{array}$ \\
\hline $\operatorname{seg} a$ & /sero/ & - calabash \\
\hline kori & $/ k^{\prime} \partial r^{\prime} /$ & $-\operatorname{coffee}$ \\
\hline hwile & Mwile/ & - has passed avay: dead \\
\hline fase & /fase/ & - under, below, down \\
\hline gohle & /rote/ & - everyuhere \\
\hline Legong & heroty & - rood, timber \\
\hline Tahwane & /tBhuare/ & - Pretoria \\
\hline leho & Mefol & - sporr. ladle \\
\hline suirí & $/ \$ 5$ ir1/ & -1 emon \\
\hline maswi & /ma»ai/ & $-m i l k$ \\
\hline pholo & $1 p^{h} 0201$ & $-a x$ \\
\hline ngwaga & $\mid$ tray $\mathbf{a} \mid$ & - year \\
\hline robja & /roß3a/ & - break, break off (paaaive of "roba") \\
\hline monna & /mona/ & $-\operatorname{man}$ \\
\hline haka & freka/ & - to hook on \\
\hline jase & /dzaae/ & - overcoat \\
\hline pats1 & pat $\int^{\prime} 1 /$ & $-\operatorname{cost}$ \\
\hline wetzove & /netf've/ & $\begin{array}{l}\text { fall towardi to fall in (causative } \\
\text { of "wela") }\end{array}$ \\
\hline kgomo & $/ \mathrm{kx}^{\prime} \mathrm{omo} /$ & - hesrd of cattle \\
\hline $11 \mathrm{a}$ & $1 \mathrm{la} /$ & $\begin{array}{l}\text { - cry; mourn; ring; strike (a bel1) } \\
\text { play a musical irstrumant; bellow; } \\
\text { yelp; mew; wistle }\end{array}$ \\
\hline pahatlea & $/ p J^{\text {that I }}$ 'a/ & $\begin{array}{l}\text { - to break (1nto plecea); break in (to } \\
\text { burgle); smagh }\end{array}$ \\
\hline rnyarie & Inenel & - sma2l, little, miniature \\
\hline mpheng & timpiens & - a handle \\
\hline gomme & Ixome/ & - and; furthermore \\
\hline thunye & /thupa/ & - cauae duat; blossom; aché: explode \\
\hline xus & /kus/ & - over there \\
\hline sebopṡa & $/$ acbop $/$ 'a/ & - creature \\
\hline mme & Inef & - my / our mother \\
\hline nina & thas & $-\mathrm{I}, \mathrm{me}$ \\
\hline ngwe & f'rue & - another \\
\hline Lefăega & flerjexa/ & - facea of diarrhoes; a coward \\
\hline IpảhInı & /ipl $J_{\text {ina }} /$ & - enjoy, be happy \\
\hline
\end{tabular}




\begin{tabular}{|c|c|c|c|c|c|}
\hline ORTHOGRAPHY & $\begin{array}{c}\text { PHONEMIC } \\
\text { TRANSCRIPTION }\end{array}$ & $\underline{\text { GLOSS }}$ & OHTHOGRAPHY & PHONENIC & $\underline{\text { gLoss }}$ \\
\hline mokgra & /mokx'va/ & - manner, cuntom, habit & nku & $/ g k^{\prime} u /$ & - sheep \\
\hline dimpla & 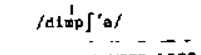 & $-\operatorname{dog} s$ & kgara & $/ \mathrm{kx}^{\prime} \mathrm{ara} /$ & - tax, hut-tax-duties \\
\hline APPENOIX 4 : & NGEPY SOTHO WORE LIST & & nna & l'na/ & - I. myself; to be ; continually \\
\hline ORTHOGHAPM & $\begin{array}{c}\begin{array}{c}\text { PHOWEOIC } \\
\text { TRANSCHIPTION }\end{array} \\
\end{array}$ & $\underline{\text { gloss }}$ & mme & Imk & - mother of; and, almo, indeed \\
\hline Ditsa & $/ p 1$ ta $a^{\circ} /$ & - pot, veasel & tehwara & /ts'sara/ & - to seize, to get hold or, to capture \\
\hline buks & buk'a/ & $-\cos x$ & kgano & $/ \mathrm{kx} \mathrm{x}^{\prime} \mathrm{smo} /$ & - a herd of cattle \\
\hline thipa & $/ t^{h} i p^{h_{B}} /$ & - knife & yaka & / jak'a & - It oeemed that \\
\hline nana & /nene/ & - meat & repha & $/ \mathrm{r}_{\mathrm{r}} \mathrm{p}^{h} \mathrm{a} /$ & - to become loobe, old \\
\hline leino & /leino/ & - tooth & & & \\
\hline kolo1 & $/ \mathrm{k}^{\prime} \mathrm{ol} \supset \mathrm{I} /$ & - vagon, car & APPENDIX 5 : TS & WORD LIST & \\
\hline kgauta & /kx'sut'a/ & - gold; a big gold or ailver bead & mantave & /menta'vef & - vorda \\
\hline nempe & /hemp'e/ & - ahirt & mo110 & /mols/ & - fire \\
\hline $\begin{array}{l}\text { qeto } \\
\text { tahela }\end{array}$ & $\begin{array}{l}\text { /Et'o/ } \\
\text { /tatela/ }\end{array}$ & $\begin{array}{l}\text { - the end, conclusion; decision } \\
\text { - to crall (o roed); to cut meat; }\end{array}$ & kgopa & $/ k x^{\prime} O p^{\prime} a /$ & $\begin{array}{l}\text { - ansil; to trip up, stumble, offend, } \\
\text { vex, displease }\end{array}$ \\
\hline & & to live i to pour & tlase & $/ \mathrm{tl}$ 'nse/ & - dow \\
\hline ntsina & $/$ ntet $^{\text {tad }}$ & - to take out, to send, to eontribute & podi & $/ p^{\prime}$ adi $/$ & $-a \operatorname{gos} t$ \\
\hline$n t j \mathbf{a}$ & $\operatorname{lnt} \int^{\prime} \mathrm{a} /$ & $\begin{array}{l}\text { - dag; despised peraon; dysentry of } \\
\text { children; very heavy atone }\end{array}$ & $\begin{array}{l}\operatorname{taie} \\
\operatorname{tahimo}\end{array}$ & $\begin{array}{l}/ \mathrm{tg}^{\mathrm{x}} \mathrm{iE} / \\
/ \mathrm{tg}^{\mathrm{i}} \mathrm{imo} /\end{array}$ & $\begin{array}{l}\text { - Locust } \\
\text { - a garden }\end{array}$ \\
\hline pjhat1s & $/ p \int^{\text {total }}$ a/ & $\begin{array}{l}\text { - to speak much, to tell; to break } \\
\text { into pieces }\end{array}$ & $\begin{array}{l}\text { thuto } \\
\text { ruri }\end{array}$ & $\begin{array}{l}\text { /thut's } \\
\text { fruri/ }\end{array}$ & $\begin{array}{l}\text { - lesson, education } \\
\text { - true }\end{array}$ \\
\hline nnete & 'ret ' $\varepsilon /$ & - truth & koko & $/ k^{\prime}$ ok'ol & - grandmother \\
\hline minoho & /mohal & - together: on one aide & moagi & $/ \operatorname{mos} 1 /$ & - a buillder \\
\hline leqhura & /let houf & - Ice & ngake & Igosk a & - a doctor \\
\hline kpaba & $/ k x^{\circ} a b a /$ & $\begin{array}{l}\text { - to be beautiful; to dress veli: } \\
\text { e spoon; to have a nice action }\end{array}$ & $\begin{array}{l}\text { nyals } \\
\text { rwele }\end{array}$ & $\begin{array}{l}\text { /rala/ } \\
\text { /rvele/ }\end{array}$ & $\begin{array}{l}\text { - to marry } \\
\text { - hat worm }\end{array}$ \\
\hline phiri & $/ p^{h i r i} /$ & - hyena & jala & /dzela/ & - plent: \\
\hline nathe & $/$ mathe/ & - saliva & tshupg & /ta"upe/ & - veavil \\
\hline ngwante & Inxana/ & $\begin{array}{l}\text { - child, Infent: tooth of baby } \\
\text { charn ueed for frightening birde owsy }\end{array}$ & Iware & /1జana/ & $\begin{array}{l}\text { - fight, quarrel, strive with each } \\
\text { other }\end{array}$ \\
\hline dijo & $/ \mathrm{di} z \partial /$ & - food; crops & tahereu & $/$ totweu/ & - wh1te \\
\hline sheshe & / Jejef & - violence; type of tree & tohwara & /ts ware/ & - hold \\
\hline dut1a & /dut1 's/ & - to leak, trickle out, arip & gagwe & /gagwe/ & - his, hers \\
\hline ditha & /dina/ & $\begin{array}{l}\text { - to cause to fall; to throu, to } \\
\text { cast down, to put into trouble }\end{array}$ & $\begin{array}{l}\text { nkgwana } \\
\text { dinku }\end{array}$ & $\begin{array}{l}\text { / jkx'rons/ } \\
/ \mathrm{d} 1 \mathrm{~g}^{\prime} \mathrm{ku} /\end{array}$ & $\begin{array}{l}\text { - a vater pot, col abash } \\
\text { - theep }\end{array}$ \\
\hline fohla & /roted & - to peel; to enlarge a hole & yaalo & $/ j$ 国1s/ & - 2ike that \\
\hline nanka & /hagk' af & - to walk proudly & nava & /mowa/ & - air \\
\hline thatia & $/$ t $1^{\prime}$ at1'a/ & - to shine: a wooden dish (for mest) & yona & / Јəna/ & $-1 t$ \\
\hline t1haka & $/ \mathrm{tt}^{\mathrm{h}} \mathrm{ok} \mathrm{a}^{\prime} /$ & - hardened ear-wax; to khout & Leswe & /leavef & - dirty, nasty \\
\hline shwaya & f! waja $/$ & to prick, to sting, cause a rash & puo & /pus/ & - apeech \\
\hline $\operatorname{tsoh} 1 e$ & $/ \mathrm{ta} \cdot \mathrm{ate} /$ & - a11, everything & tau & $/ \mathrm{t}^{* a u} /$ & $-110 n$ \\
\hline tshrepha & /tst wet pha/ & - to tuist, entwine & kobo & /xabo/ & - a kaross; blanket \\
\hline motsho & /motsho/ & - black & se jo & /aedza/ & - food \\
\hline qaqa & /a!a/ & - to be plsin, evident & nвma & /nama/ & - meat \\
\hline monna & /mona/ & - man, husband & rre & InE & - father, my father \\
\hline tjotja & $\left./ \mathrm{t}]^{\prime \prime a t}\right]_{1}^{\prime a} /$ & - to continue raining & gotlhe & $/ x_{J} t 1^{h} /$ & - entirely, all \\
\hline ejhella & $/ t^{h}+1.9 /$ & - damage sustained through fire & pitsi & $/ p^{\prime} i t s ' 1 /$ & - a horse: a zebra \\
\hline mot jhi & $f$ mot $]^{n} I /$ & I- not, anywhere & tshlp 1 & $/ \operatorname{tsh}^{\prime} \mathrm{p}^{\prime} \mathrm{i} /$ & - iron, metal \\
\hline kgwahla & /kx'vata/ & $\begin{array}{l}\text { - to rum: to become atrong, firm; } \\
\text { to shrivel up }\end{array}$ & khudu & /khudu/ & - tortolse \\
\hline sitsa & /a1ts'a/ & $\begin{array}{l}\text { - to go and live in a foreign piace } \\
\text { - to give, to grant. to favour oith }\end{array}$ & thaba & /t2haba/ & $\begin{array}{l}\text { - to gather, collect } \\
\text { - to alaughter, atab }\end{array}$ \\
\hline $\operatorname{mad} i$ & /madi/ & - blood; beer & kgopho & $/ k x^{\prime}$ opho/ & $\begin{array}{l}\text { - to alaughter, atab } \\
\text { - B small bush with edible frult }\end{array}$ \\
\hline pjhanya & /p J'ana/ & - to speak, to say & phepha & $/ \mathrm{p}^{h} \varepsilon \mathrm{p}^{h} \mathrm{a}^{\prime} /$ & $\begin{array}{l}\text { - } 8 \text { small bush with edible frult } \\
\text { - clean }\end{array}$ \\
\hline Djatla & /p J'at $1{ }^{\prime} a /$ & - to boil vell & fofa & /fofo/ & $\begin{array}{l}- \text { clean } \\
-f l y:\end{array}$ \\
\hline tosa & $/ t^{\prime}$ Jaa/ & - to stretch out, to raise & vesi & /×Eai/ & $\begin{array}{l}-11 y \text { : } \\
\text { - om; slone }\end{array}$ \\
\hline bjaratsa & błarats's & - ta crunch, to 6 maeh & tefo & terest & - payment \\
\hline nyorwa & $f_{f}^{1}$ & - to becone thirsty & aenys & /sena/ & - spoill \\
\hline $11 a$ & /at & - weep, cry, emit a gound, bellor & rrague & traxwe/ & - h1s rather \\
\hline pyheha & $/ \mathrm{p}^{\mathrm{h}} \mathrm{h}_{\mathrm{ha}} / \mathrm{f}$ & - to have diarrhoea, to be purged; & $\operatorname{mnidi}$ & imidis & - meslie \\
\hline & & $\begin{array}{l}\text { to act in a covardly manner } \\
\text { to divide, hand out, distribute }\end{array}$ & nnye & /nef & - 1ittle \\
\hline abjwa & /abjoal & $\begin{array}{l}\text { - to divide, hand out, distribute } \\
\text { - tears (n) }\end{array}$ & nnetzane & 'netr'ane/ & - gomething \\
\hline mookgo & $/ m \partial \cdot k x^{\prime} \partial /$ & - tears $(n)$ & nkga & $/ n k x x^{\prime}=/$ & - to em1t a smell \\
\hline hlatsua & /tata'va/ & - to wash & throye (tsebe) & /t2htheajo/ & - to 11 sten carefully \\
\hline lef jwa & /lef wat & - to be paid & $11 \mathrm{a}$ & in & $-\operatorname{cry}$ \\
\hline
\end{tabular}

Die Suid-Afrikaanse Tydskrif vir Kommunikasieafwykings, Vol. 33. 1986 


\begin{tabular}{|c|c|c|}
\hline ORTHOGEAPHYY & $\begin{array}{c}\text { PHONEMTC } \\
\text { TRANSCRIPTION }\end{array}$ & $\underline{\text { GLOSS }}$ \\
\hline lwantsho & /1wantsha/ & $\begin{array}{l}\text { - cause to quarrel or strive with } \\
\text { each other }\end{array}$ \\
\hline lotéza & $1100 \int^{\prime} \mathrm{wB} /$ & - be requ1red, demanded, asked for \\
\hline mpho & $/ m^{n} \mathrm{~s} /$ & $-g^{\text {ift }}$ \\
\hline eekhi & $/ \mathbf{s e k}^{h_{1}} /$ & - a specics of thorrly bush \\
\hline aupe & /supe/ & - to show, point; seven \\
\hline aebs & /afba/ & - to whisper. to backbite \\
\hline aga & /axa/ & - to build; Live, dwell \\
\hline ritins & $/ \mathrm{f}^{\prime} \mathrm{t}^{\mathrm{h}} \mathrm{a} /$ & - to arrive; to bury, hide \\
\hline kgakge & $/ \mathrm{kx}^{\prime} \mathrm{akx} \mathrm{x}^{\prime} \mathrm{cl}$ & - vonder, astonishment \\
\hline maš1 & $/ \mathrm{ma} \int \mathrm{wi} /$ & $-\pi 11 \mathbf{k}$, sweet milk \\
\hline taoma & $/ \mathrm{ta}^{\prime} \mathrm{ama} /$ & - to hunt \\
\hline dikg*e & /dikx'va/ & - clumps of bush \\
\hline $\min 1 \mathrm{n} 1$ & /mini/ & - dancer \\
\hline bonnye & /topal & - emeller \\
\hline setánaba & fse: $\int$ habef. & - nation \\
\hline thetss & /t] hota $^{\prime} \mathrm{B} /$ & - vonit \\
\hline sotthe & $\mid x \operatorname{sot}^{1} \mathrm{~h}_{\mathrm{B}} /$ & - rub a surface \\
\hline menga & $/$ moral & - dex; mlat \\
\hline
\end{tabular}

\section{REFERENCES}

Baragwanath Hospital, Department of Speech Therapy and Audiology. Speech discrimination testing materials: Zulu and Sotho. Soweto, 1977.

Beukelman, D.R. and Yorkston, K.M. The relationship between information transfer and speech intelligibility of dysarthric patients. Joumal of Communication Disorders, 12, 189-196, 1979.

Black, J.W. Accompaniments of word intelligibility. Journal of Speech and Hearing Disorders, 17, 409-418, 1952.

Black, J.W. Multiple-choice intelligibility tests. Journal of Speech and Hearing Disorders, 22, 213-235, 1957.

Brown, J.T. Setswana-English Dictionary. Third Edition. Botswana Book Centre (U.C.S.S.A.), 1971.

Cole, D.T. An Introduction to Tswana Grammar. London: Longmans, Green and Co., 1955.

Darley, F.L., Aronson, A.E. and Brown, J.R. Motor Speech Disorders. London: Saunders, 1975.

Doke, C.M. Text-Book of Zulu Grammar. Second Edition. London: Longmans, Green and Co., 1931.

Doke, C.M. and Mofokeng, S.M. Textbook of Southern Sotho Grammar. Cape Town: Longmans, Green and Co., 1957

Egan, J.P. Articulation testing methods. Laryngoscope, 58, 955991,1948

Fairbanks, G. Test of phonemic differentiation: The Rhyme Test. Journal of the Acoustical Society of America, 30(7), 596-600, 1958

Fairbanks, G. Voice and Articulation Drillbook. Second Edition, New York: Harper and Row, 1960.

Gowlett, D.F. and Rassman, E.F.A. Word-frequency count for Southern Sotho prose literature. African Studies, 38(2), 107$133,1979$.

Griesel, G.J. Die invloed van 'n Kwantitatiewe Taaltonleding op Leerstofseleksie by die Onderrig van Zoeloe as Tweede Taal. Master's dissertation, University of Natal, Pietermaritzburg, 1979.

Griggs, T. From articulation tests towards formulas for intelligibility. Language and Speech, 1, 194-221, 1958.

Hillbrow Hospital, Department of Speech Therapy and Audiology. Phonetic inventories: Zulu and Southern Sotho., Johannesburg, 1981.

Hirsh, 1.J., David, H. Silverman, S.R., Reynolds, E.G., Eldert, E. and Benson, R.W. Development of materials for speech audiometry. Journal of Speech and Hearing Disorders, 17, 321-337, 1952.
Hodson, B.W. and Paden, E.P. Targeting Intelligible Speech: A Phonologic Approach to Remediation. San Diego: CollegeHill Press, 1982.

Hollenbeck, A.R. Problems of reliability in observational research. In Sackett, G.P. (Ed.) Observing Behaviour Vol. II: Data Collection and Analysis Methods. NICHD Mental Retardation Series, Baltimore: University Park Press, 1978.

Jacobson, M.C. Speech Intelligibility and Articulatory Dynamics of Reconstructed Oral Cancer Patients. Ph.D. Thesis. University of the Witwatersrand, Johannesburg, 1986.

Jordan, A.C. A Practical Course in Xhosa. Cape Town: Longmans, 1966.

Khumalo, S.J.M. Zulu Tonology. Master's dissertation. University of the Witwatersrand, Johannesburg, 1981.

Kipfmueller, L.T. and Prins, T.D. Consonant Intelligibility: Reliability and validity of a speech assessment procedure. Journal of Speech and Hearing Research, 14, 559-564, 1971.

Kunene, D.P. The Ideophone in Southern Sotho. Marburger Studien Zur Afrika und Asienkunde. Berlin: Verlag Von Dietrich Reimer, 1978.

Kyle, J.G., Conrad, R., McKenzie, M.G., Morris, A.J.M. and Weiskrantz, B.C. Language abilities in deaf school leavers. Teacher of the Deaf, 2, 38-42, 1978.

Lanham, L.W. An outline history of the languages of Southern Africa. In L.W. Lanham and K.P. Prinsloo (Eds.), Language and Communication Studies in South Africa. Cape Town: Oxford University Press, 1978.

Lehiste, I. and Peterson, G.E. Linguistic considerations in the study of speech intelligibility. Journal of the Acoustical Society of America, 31(3), 280-286, 1959.

Mabille, A. and Dieterlen, H. Southern Sotho-English Dictionary. Revised by Paroz, R.A. Revised and enlarged eighth edition. Basutoland: Morija, 1961.

Markides, A., Assessing the speech intelligibility of hearing impaired children: Oral reading versus picture description. Teacher of the Deaf, 2, 185-189, 1978.

Meyerson, M.D., Johnson, B.H. and Weitzman, R.S. Rehabilitation of a patient with complete mandibulectomy and partial glossectomy. American Journal of Otolaryngology, 1, 256-261, 1980

Miller, G.A., Heise, G.A. and Lichten, W. The intelligibility of speech as a function of the context of the test materials. Journal of Experimental Psychology, 41, 329-335, 1951.

Nichols, A.C. Confusions in recognising phonemes spoken by esophageal speakers: I. Initial consonants and clusters. Joumal of Communication Disorders, 9, 27-41, 1976.

Platt, L.J., Andrews, G., Young, M. and Neilson, P.D. The measurement of speech impairment of adults with cerebral palsy. Folia Phoniatrica, 30, 50-58, 1978.

Prather, E.M. Scaling defectiveness of articulation by direct magnitude estimation. Journal of Speech and Hearing Research, 3(4), 380-392, 1960.

Rosenbek, J.C. and LaPointe, L.L. The dysarthrias: Description, diagnosis and treatment. In D.F. Johns (Ed.), Clinical Management of Neurogenic Communicative Disorders. Boston: Little, Brown, 1978.

Sackett, G.P. Measurement in observational research. In G.P. Sackett (Ed.), Observing Behaviour. Vol. II: Data Collection and Analysis Methods. NICHD Mental Retardation Series. Baltimore: University Park Press, 1978.

Schiavetti, N., Metz, D.E. and Sitler, R.W. Construct validity of direct magnitude estimation and interval scaling of speech intelligibility: Evidence from a study of the hearing-impaired. Joumal of Speech and Hearing Research, 24, 441-445, 1981.

Schiavetti, N., Sitler, R.W., Metz, D.E. and Houde, R.A. Prediction of contextual speech intelligibility from isolated

(Continued on Page 28) 

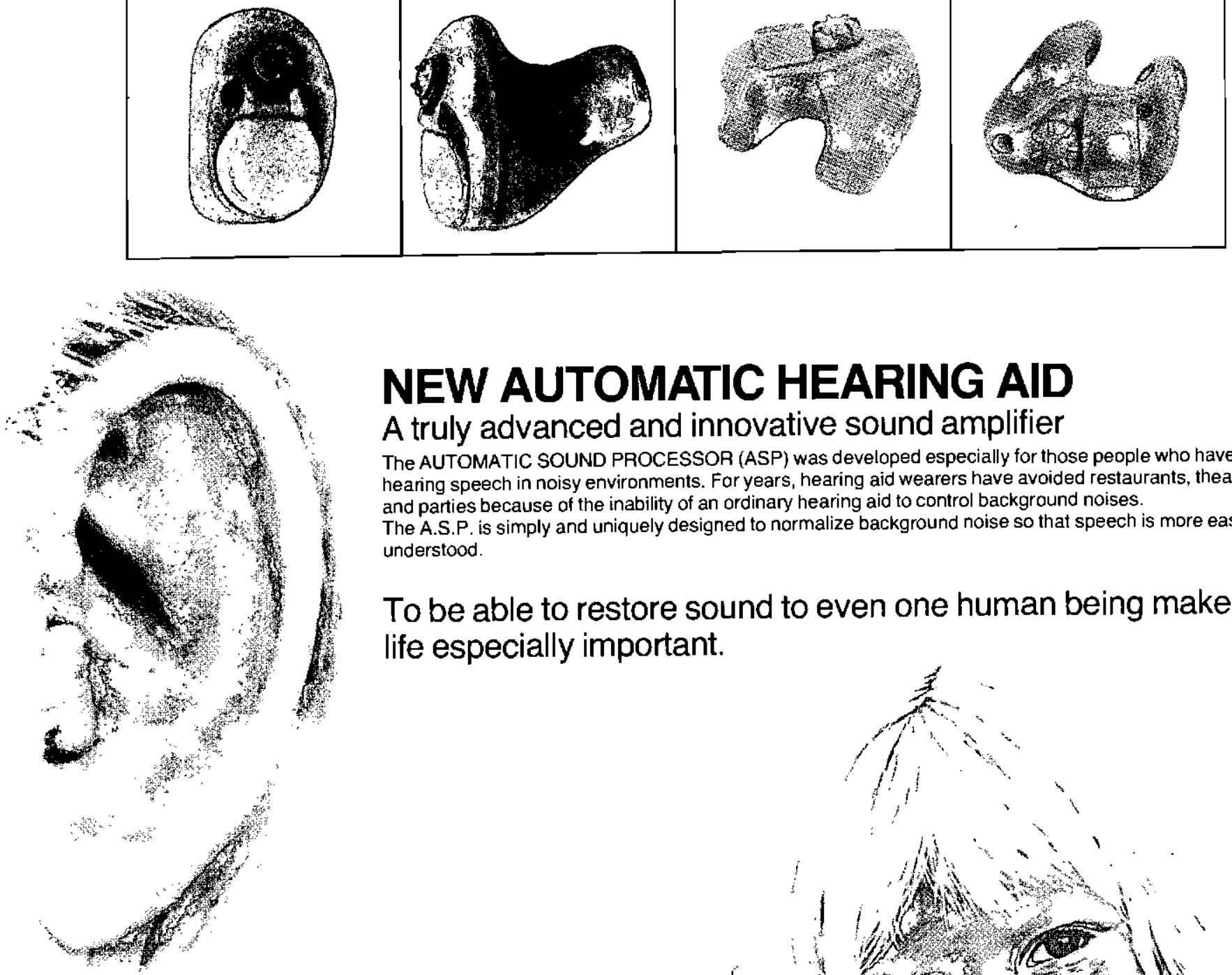

\section{NEW AUTOMATIC HEARING AID}

\section{A truly advanced and innovative sound amplifier}

The AUTOMATIC SOUND PROCESSOR (ASP) was developed especially for those people who have difficulty in hearing speech in noisy environments. For years, hearing aid wearers have avoided restaurants, theatres, church and parties because of the inability of an ordinary hearing aid to control background noises.

The A.S.P. is simply and uniquely designed to normalize background noise so that speech is more easily understood.

To be able to restore sound to even one human being makes your life especially important.

To restore hearing... what a blessed talent to have

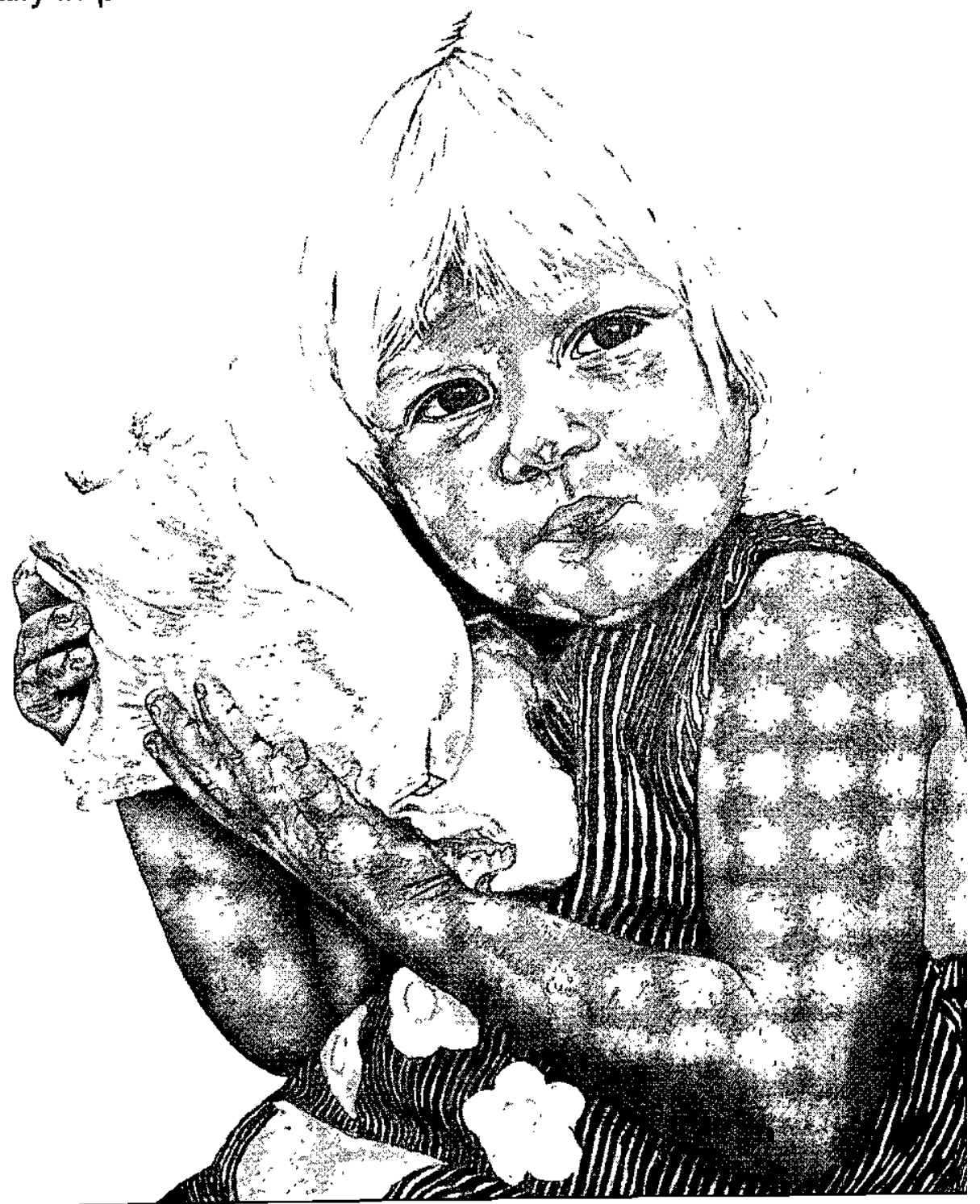

MEDIFIX (РTY)เTD.
SURGICAL \& MEDICAL P.O. Box 19 Bedfordview 2008

South Africa
Phone: (011) 53-4188/9

\section{$\frac{\text { CAPE }}{\text { P.O. Box } 52}$} Lynedoch 7603 Phone: (02234) 442 or (02231) 93442
NATAL

P.O. Box 47443

Greyville

4023

Phone: (031) 236164

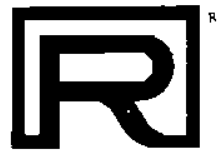

RICHARDS hearing systems 
(Continued from Page 26)

word intelligibility measures. Journal $f$ Speech and Hearing Research, 27, 623-626, 1984.

Schmidt, S. Intelligibility and the child with multiple articulation deviations. In H.A. Winitz (Ed.), Treating Articulation Disorders: For Clinicians by Clinicians. Baltimore: University Park Press, 1984.

Schultz, M.C. World familiarity influences in speech discrimination. Joumal of Speech and Hearing Research, 7, 395-400.

Shriberg, L.D. and Kwiatkowski, J. Phonological disorders III: A procedure for assessing severity of involvement. Journal of Speech and Hearing Disorders. 47, 242-256, 1982.

Skelly, M. (ed.) Glossectomee Speech Rehabilitation. Springfield, Illinois, Charles C. Thomas, 1973.

South Africa 1985: Official Yearbook of the Republic of South Africa. Eleventh Edition. Johannesburg: Chris van Rensburg, 1985.

Tikofsky, R.S. A revised list for the estimation of dysarthric single word intelligibiliy. Journal of Speech and Hearing Research, 13, 59-64, 1970.

Tobias, J.V. On Phonemic analysis of speech discrimination tests. Journal of Speech and Hearing Research, 7, 98-100, 1964.

Van Wyk, E.B. Language Contact and Bilingualism. In L.W. Lanham and K.P. Prinsloo (Eds.), Language and Communication Studies in South Africa. Cape Town: Oxford Univer-
Wilkes, A. Bantu Language Studies. In L.W. Lanham and K.P. Prinsloo (Eds.), Language and Communication in South Africa, Cape Town: Oxford University Press, 1978.

Yorkston, K.M. and Beukelman, D.R. A comparison of techniques for measuring intelligibility of dysarthric speech. Journal of Communication Disorders, 499-512, 1978.

Yorkston, K.M. and Beukelman, D.R.A. A clinician-judged technique for quantifying dysarthric speech based on single word intelligibility. Joumal of Communication Disorders, 13, 15-31 1980.

Yorkston, K.M. and Beukelman, D.R. Communication efficiency of dysarthric speakers as measured by sentence intelligibility and speaking rate. Journal of Speech and Hearing Disorders, 46, 296-301, 1981.

Young, M.A. and Downs. T.D. Testing the significance of the agreement among observers. Journal of Speech and Hearing Research, 11, 5-17, 1968.

Ziervogel, D., Louw, J.A., Ferreira, J.A., Baumbach, E.J.M. and Lombard, D.P. Handbook of the Speech Sounds and Sound Changes of the Bantu Languages of South Africa, Unisa Handbook Series No. 3E. University of South Africa, Pretoria, 1967.

Ziervogel, D., Louw, J.A. and Taljaard, P.C. A Handbook of the 